\title{
The testing research on horizontal bearing capacity for the cast - in - place pile socketed in rock
}

\author{
Dong Wang ${ }^{1, a}$, Yin Cheng ${ }^{2, b}$ \\ ${ }^{1}$ China Road and Bridge Corporation, Beijing 100011, China; \\ ${ }^{2}$ Beihang University, Beijing 100191, China; \\ awangdong-yc@163.com, b306876662@qq.com
}

Keywords: Rock-socketed pile, Horizontal bearing capacity

\begin{abstract}
In order to study the characteristics of the lateral bearing capacity for the case-in-place pile socked in rock, a single pile lateral load test is conducted in site, in which, some instrument were installed in pile shaft, and the deflections in the pile top and the steel bar stresses were taken under the various loadings, and propose a number of recommendations to improve the horizontal bearing capacity of the single pile.
\end{abstract}

\section{Introduction}

In contrast with shallow foundation, the pile foundation has better engineering characteristics of high bearing capacity, small settlement and more suitable for mechanized construction, which is easy to adapt to the different requirements of foundation engineering, so the pile foundation has been widely used in civil engineering.

As one form of pile, the rock-socketed pile was widely used in construction work in the past two decades, and has made significant economic benefits ${ }^{[1,2]}$. However, due to the shorter application time and the research is not thorough, especially lack of the research on the horizontal bearing capacity, the use of rock-socketed pile is limited. So this research is focused on test and analysis with the bearing behavior and change rules of internal forces of rock-socketed pile under horizontal loads, thus draw some useful recommendations on the engineering design of the rock-socketed pile $^{[3,4]}$.

\section{Experimental methods}

The test site is located in an aluminum plant's construction site in Yangquan, Shanxi province. The four rock-socketed piles are poured in the construction site, and the position of pile is symmetrically distributed. The diameter of pile is $1 \mathrm{~m}$, the long of pile is $7 \mathrm{~m}$ with the bottom of pile was embedded in rock with $1 \mathrm{~m}$ long, the distance between pile centers is $3 \mathrm{~m}$, the four piles are named 1\#, 2\#, 3\#, 4\#. The specific arrangement diagram of the pile is showed in Fig 1.

The geological conditions of test site: the landform of the site is part of Taihang mountain, and the design elevation is $802.0 \mathrm{~m}$. According to the geological survey, the soil can be divided into five levels, respectively miscellaneous fill, plain fill, silty clay, strongly weathered sandstone and intermediary weathered sandstone. The groundwater level of soil is unstable and the amount of water is small.

Test equipment are including loading device, reference unit and measuring device, the load of test is applied in equal increments by jack, the steel bar stress is measured by CTY-202 vibrating wire rebar stress meter which are layout on the longitudinal reinforcement (Fig 1) and the horizontal displacement on pile is measured by dial indicator. The pile stress, distribution of bending moment and horizontal displacement on pile in the loading process are measured by above equipment, and calculate the horizontal bearing capacity of the pile at last.

The specified diameter and depth pile is digged by construction machinery, $20 \quad \Phi 16$ reinforcement bars are used as longitudinal reinforcements in pile and $\Phi 8$ spiral ribs are used as stirrups, which are composing steel mesh cage (Fig 1). The completed steel mesh cage is hoisted 
into the pile hole after the hole is complete, then pour the concrete which is $\mathrm{C} 25$ grade.
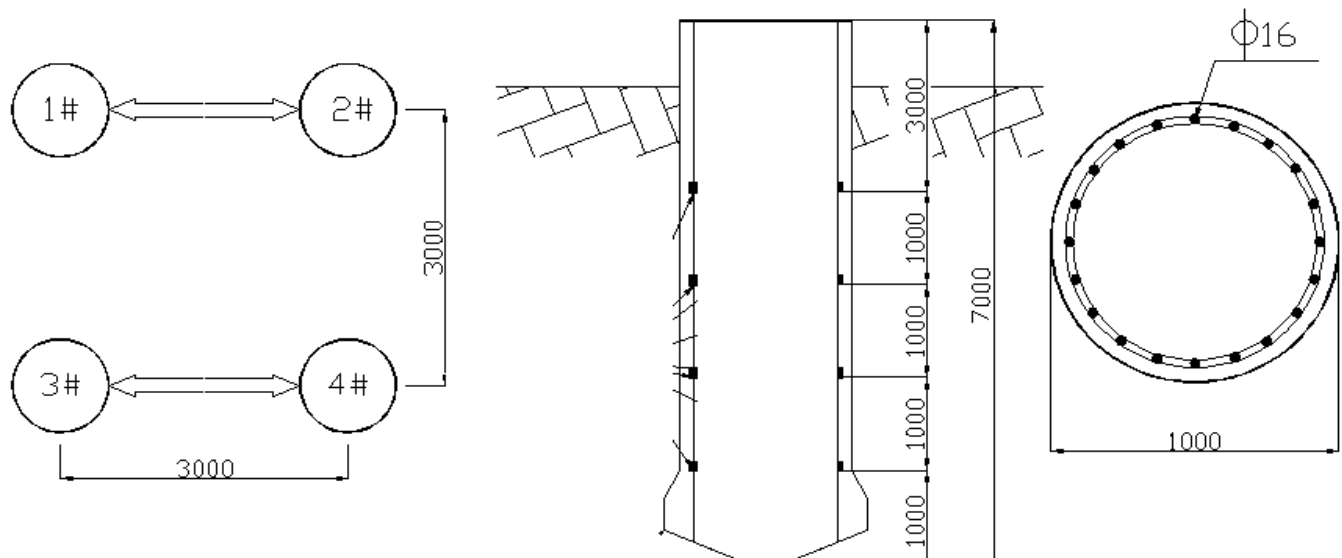

Fig 1 The specific arrangement diagram of the pile

Two groups of single pile are tested by single pile's horizontal bearing capacity. $1 \#$ and $2 \#$ is a test group and $3 \#$ and $4 \#$ is another. $1 \#$ and $2 \#$ test group is tested at first, the jack is installed between two piles, and the horizontal force line is through center of piles, the test load is unidirectional cyclic loading and unloading. After completing the test of $1 \#$ and $2 \#$, the $3 \#$ and $4 \#$ group followed, and the test process is the same as above.

\section{Results and discussion}

Test results include load value, horizontal displacement of pile top, steel bar stress of pile shaft under each stage of loading, in order to simplify the research, the $1 \#$ and $3 \#$ piles are selected to do the study. The distribute of steel bar stress along the $1 \#$ pile in single pile static load test is presented in Fig.2, the distribute of steel bar stress along the 3\# pile in single pile static load test is presented in Fig.3, H-Y0(horizontal load-horizontal displacement) curve for 3\# pile in single pile static load test is presented in Fig.4.

From Fig 2 and Fig 3 we can find out that, the pile shaft close to the jack is withstand tensile stress and the other side is withstand compressive stress, tensile stress and compressive stress are substantially symmetrical distribution. From figure it is also seen that stress in the middle of pile shaft is large, and stress in the pile top and pile bottom are relatively small. From Fig 4 it is clear that the horizontal displacement on $3 \#$ pile top is relatively small, when load application is near $210 \mathrm{kN}-240 \mathrm{kN}$, a small platform is appeared in the curve, the horizontal displacement in this range is almost unchanged, after this range the displacement is slowly change again.

In order to determine the horizontal critical load and ultimate load of pile, $\mathrm{H}-\mathrm{Y} 0 / \mathrm{H}$ (horizontal load-displacement gradient) curve for $3 \#$ pile is presented in Fig. 5 and $\mathrm{H}-\sigma$ (horizontal load-steel bar stress in maximum moment section) curve for 3\# pile is presented in Fig.6.
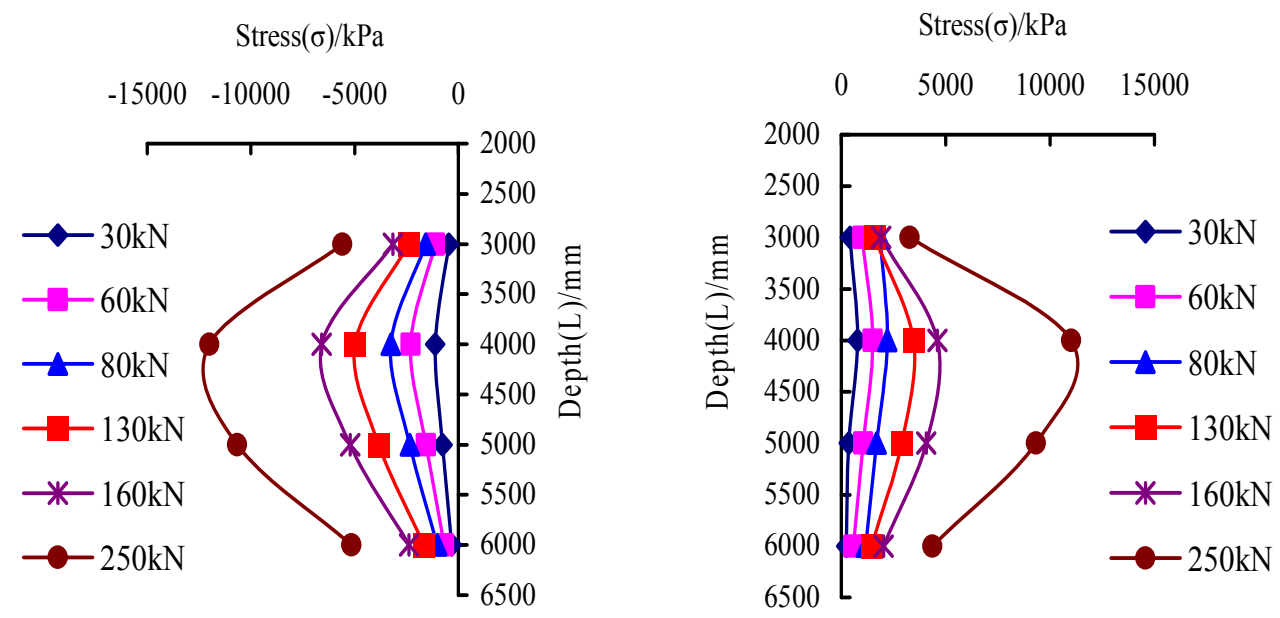

Fig 2 The distribute of steel bar stress along the 1\# pile in single pile static load test 

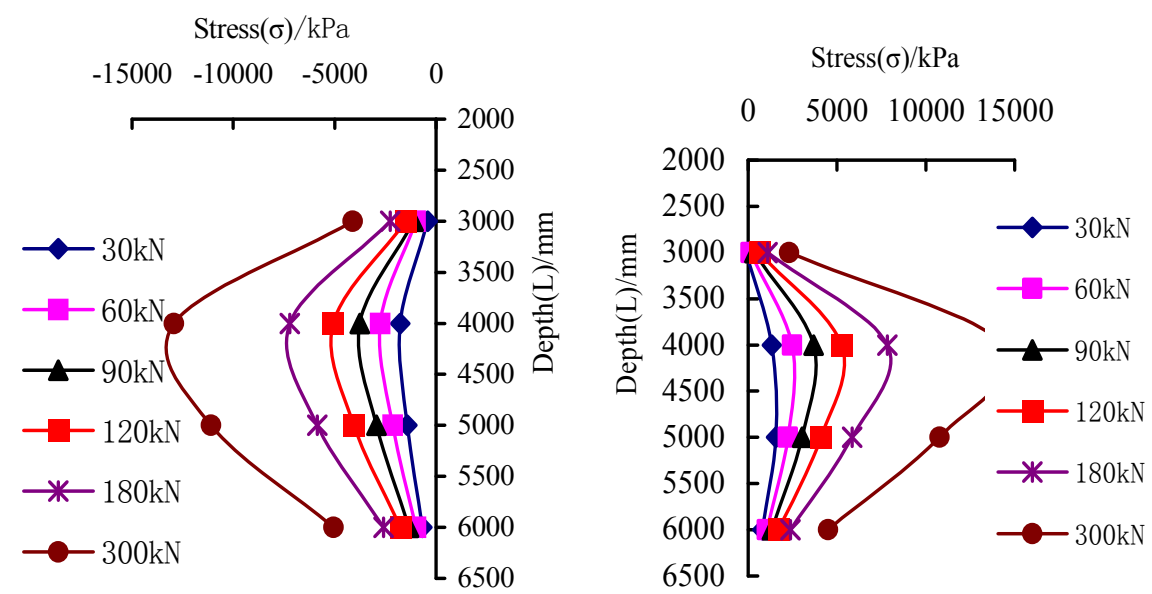

Fig 3 The distribute of steel bar stress along the 3\# pile in single pile static load test

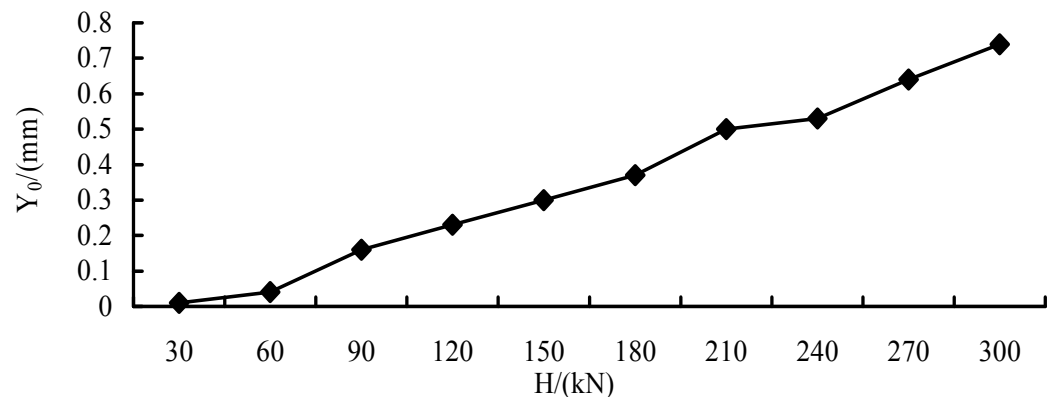

Fig $4 \mathrm{H}-\mathrm{Y}_{0}$ curve for $3 \#$ pile in single pile static load test

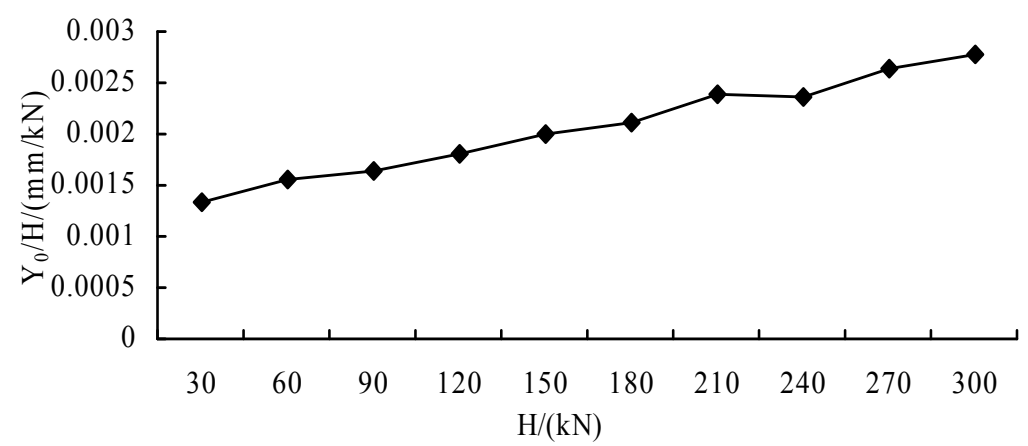

Fig $5 \mathrm{H}-\mathrm{Y}_{0} / \mathrm{H}$ curve for $3 \#$ pile

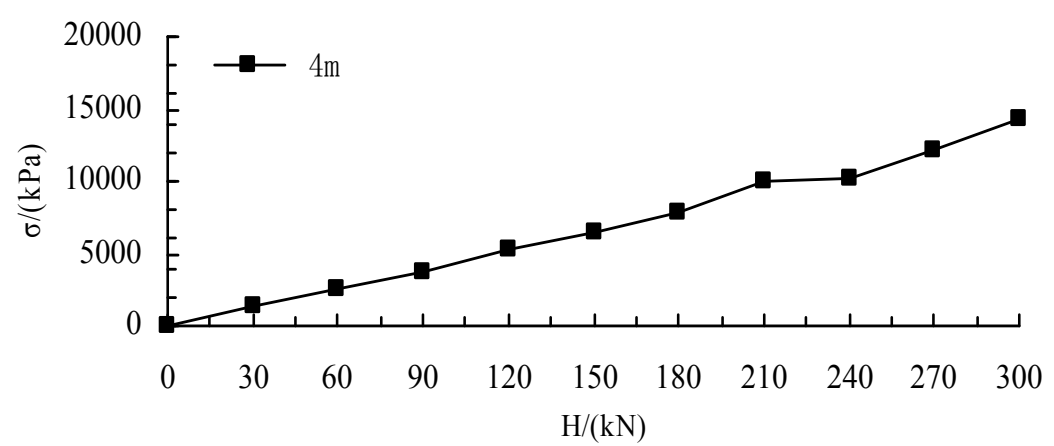

Fig 6 H-øcurve for $3 \#$ pile

Fig 5 and Fig 6 reveal that the $\mathrm{H}-\mathrm{Y} 0 / \mathrm{H}$ curve and $\mathrm{H}$ - $\sigma$ curve for $3 \#$ is coordinated, the curve trend is similar and in the range of $210 \mathrm{kN}-240 \mathrm{kN}$ is turning into a platform.

Critical load is defined as the load bring out the tension zone of maximum moment section appearing cracks which are develop to protective layer. The determination of critical load contain three methods: the load before mutation in $\mathrm{H}-\mathrm{Y} 0$ curve; the load which is corresponding to the end point of first horizontal line segment in $\mathrm{H}-\mathrm{Y} 0 / \mathrm{H}$ curve; the load before mutation in $\mathrm{H}$ - $\sigma$ curve[ $[5,6]$.

Ultimate load is defined as the maximum load which a structure is designed to withstand without a failure. The definition of ultimate load also contain three methods: the load which is 
corresponding to the obvious turning point in $\mathrm{H}-\mathrm{Y} 0$ curve; the load which is corresponding to the end point of second horizontal line segment in $\mathrm{H}-\mathrm{Y} 0 / \mathrm{H}$ curve; the load before the reinforcement limit reach ductility limit $[5,6]$.

According to test data it is clear that displacement in pile top is small, which satisfy allowable value of horizontal displacement, while according to the specification, take the load before mutation in H- $\sigma$ curve as the critical load, each critical load of single pile is determined which are presented in Tab 1.

Tab 1 The results of single pile test

\begin{tabular}{|c|c|c|c|c|}
\hline Item & $1 \#$ & $2 \#$ & $3 \#$ & $4 \#$ \\
\hline Horizontal critical load Hcr/kN & 210 & 210 & 210 & 210 \\
\hline $\begin{array}{c}\text { Displacement in pile top } \\
\text { according to the critical load } \\
\text { Xcr/mm }\end{array}$ & 0.42 & 0.51 & 0.49 & 0.4 \\
\hline $\begin{array}{c}\text { The depth from earth's surface to } \\
\text { maximum moment section /m }\end{array}$ & 4 & 4 & 4 & 4 \\
\hline
\end{tabular}

Tab 1 shows that each test pile's displacement under the critical load is less than the standard value, so the critical load can be regard as the design load of test pile. Small displacement of pile top is determined by site's environment and pile's form. In this test, the soil of site have amount of large rocks, which make the performance of soil pressure much better, and result in that the displacement of pile top is not particularly obvious. Then the test pile's form is rock-socketed short and thick pile, the pile's bottom is embedded in the rock, all these reasons are cause the displacement of pile top is not significant. The situation of test piles is showed in Fig 7.

In this test, there is not appear three cases of determination method of ultimate load, because the soil of site contain a lot of stone, and the pile's form is rock-socketed short and thick pile, all these reasons cause the ultimate load of test pile couldn't define.
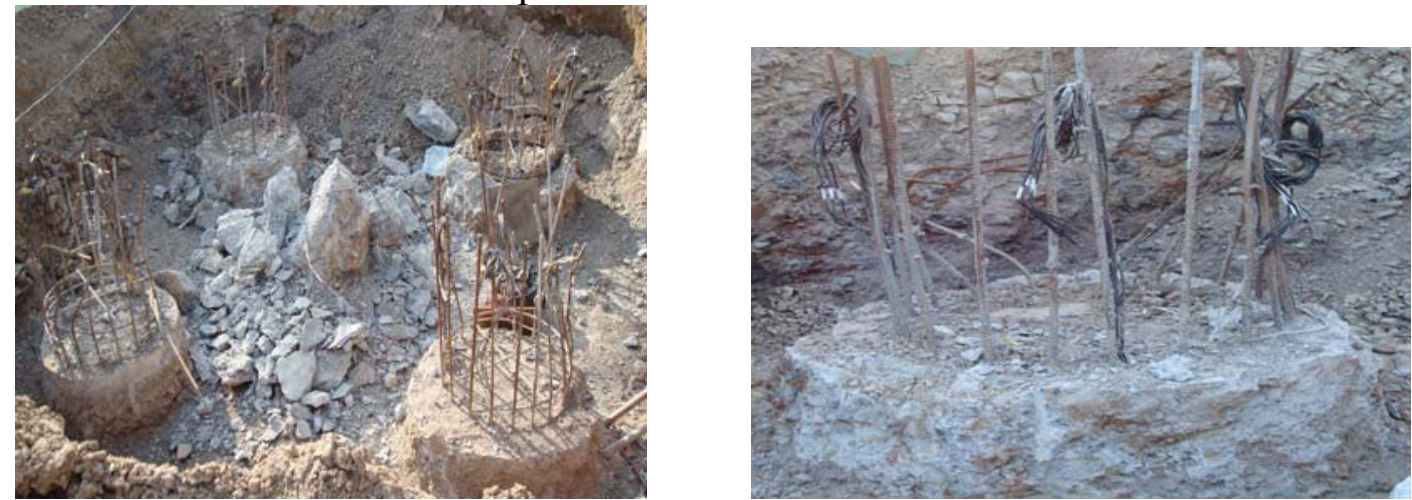

Fig 7 The situation of test piles

From test data can also be seen, the horizontal deformation of pile is closely related to the horizontal bearing capacity of single pile. Therefore, in order to improve the horizontal bearing capacity of pile, we must increase the stiffness and strength of pile. Improve the label of concrete, change the form and shape of pile and plus casing in the largest moment section of pile are used to improve the stiffness and strength of the pile.

\section{Conclusions}

1) Test pile's displacement under the critical load is less than the standard value, so the critical load can be regard as the design load of test pile.

2) In this test, the soil of site have amount of large rocks, which is make the performance of soil pressure much better, and then the test pile's form is rock-socketed short and thick pile, the pile's bottom is embedded in the rock, all these reasons are cause the displacement of pile top is not significantly. 
3) The maximum bending moment of pile is in the middle of pile and $4 \mathrm{~m}$ away from pile top which is measured by vibrating wire rebar stress meter layout on the longitudinal reinforcement.

4) In this test, there is not appear the ultimate load of the pile, which is ascribed by test site's geological condition and test pile's form.

5) The method of improve the horizontal bearing capacity of pile is used to increase the stiffness and strength of pile.

\section{Reference}

[1] X.Z.Fei, C.H.He, Y.F.Cheng. A study of horizontal bearing capacity of single pile. Rock and Soil Mechanics, Vol.23(2003), p.545-549.

[2] Li'an Han, Calculation of the horizontal bearing piles (Central South University Press, Changsha 2004)

[3] Qiang Huang, The hot technology issues of pile foundation engineering(China Architecture \& Building Press, Beijing 1996)

[4] S.Q.Niu, J.L.Zhang, Y.G.Zhao. Analisis and estimation of experimental data for piles under horizontally static loads. City Survey, Vol.4(2006), p76-79.

[5] Technical Code for Building Pile Foundations (JGJ 94-2008) (China Architecture \& Building Press, Beijing1995)

[6] Technical Code for Testing of Building Foundation Piles (JGJ 106-2003 J256-2003) (China Architecture \& Building Press, Beijing 2003) 